months in those who received the same chemotherapy together with BCG. In the group receiving specific active immunotherapy most relapses were in the lymphatic drainage area of the primary tumour, unlike in the controlled group, whose relapses were at distant sites. An earlier study ${ }^{17}$ reported a similar trend to relapse early in patients receiving immunotherapy with BCG and irradiated cells.

These reports emphasise that we should be cautious in setting up new immunotherapy trials and that the results of existing trials should be studied critically in the light of what we know. More important, we need further laboratory studies to examine the principles which justify immunotherapy in treatment. Until we have such results, Woglom's observation ${ }^{2}$ of 50 years ago remains essentially true.

\footnotetext{
${ }^{1}$ Behring, E, and Kitasato, S, Deutsche Medizinische Wochenschrift, 1890, 16, 1113.

2 Woglom, W H, The Cancer Review, 1929, 4, 129.
}

${ }^{3}$ Currie, G A, LeJeune, F, and Fairley, G H, British Medical fournal, 1971, 2, 305.

4 Currie, G A, British fournal of Cancer, 1973, 28, 25.

5 Currie, G A, and McElwain, T J, British fournal of Cancer, 1975, 31, 143.

6 Gutterman, J U, et al, Seminars in Oncology, 1975, 2, 155.

${ }^{7}$ Holmes, E C, Eilber, F R, and Morton, D L, fournal of the American Medical Association, 1975, 232, 1052.

${ }^{8}$ Miller, E E, et al, fournal of Surgical Oncology, 1976, 8, 31

${ }^{9}$ Cunningham, T J, et al, Annals of the New York Academy of Sciences, 1976, 277, 339.

${ }^{10}$ Rosato, F E, et al, Annals of the New York Academy of Sciences, 1976, 277, 332.

11 Rosato, F E, Miller, E, and Rosato, E F, Virginia Medical Monthly, 1978, 105, 221.

12 Rosato, F E, et al, Surgery, Gynecology and Obstetrics, 1974, 139, 675

13 Stewart, T H M, et al, Canadian fournal of Surgery, 1977, 20, 370.

${ }^{4}$ Green, A A, et al, Annals of the New York Academy of Sciences, 1976, 277, 396.

15 Bekesi, J G, et al, Proceedings of the American Association for Cancer Research and American Society of Clinical Oncology, 1976, 17, 184.

${ }^{16}$ Hedley, D W, McElwain, T J, and Currie, G A, British fournal of Cancer, $1978,37,491$.

17 McIllmurray, M B, et al, British Medical fournal, 1977, 1, 540.

\title{
Menetrier's disease
}

Menetrier's disease is a good example of the inverse relation between the incidence of a disorder and the interest it generates. ${ }^{1-3}$ This curious disease-characterised by gross mucosal hypertrophy, hyposecretion of gastric acid, excess loss of protein from the stomach, diminished gastric motility, oedema, weight loss, anorexia, nausea and vomiting, and sometimes diarrhoea-is exceedingly rare, yet we understand its natural history, complications, and management better than those of more common gastric diseases.

The disorder is about three times more common in men than women, being most often diagnosed in people between 30 and 50. It does not appear to be directly inherited and is almost certainly acquired in adult life, though the history of symptoms often extends over many years. A similar but possibly distinct disorder has been reported in children. Patients may have a higher-than-average incidence of cardiovascular thrombotic disease, which may in turn contribute to their increased death rate, and probably an increased risk (similar to that in atrophic gastritis) of both primary and secondary carcinoma of the stomach. Some reports have noted various allergies.

The mucosal changes are gross, and both barium meal $x$-ray films and inspection by the naked eye at operation show large, heaped-up folds like the convolutions of the brain. The changes affect either parts of the stomach or the entire organ, generally being greatest in the fundus with relative sparing of the antrum. Full-thickness biopsy specimens should be taken at endoscopy. Microscopically, these show proliferation of all mucosal cells, but of the mucus-secreting more than the parietal and pepsin cells. There may also be lymphoid hyperplasia.

Although we do not know what causes this alteration of the mucosa, two interesting hypotheses are suggested by the results of recent investigations. Firstly, certain hormones of the upper gastrointestinal tract (for example, gastrin) exert a direct trophic effect on the gastric mucosa, and an exaggerated mucosal response might result from a disorder of this trophic mechanism. ${ }^{4}$ Secondly, the mucosal proliferation may be a response to excessive regurgitation of the contents of the small intestine through the pylorus. The possibly harmful effect of bile salts, lysolecithin, and other constituents as a factor in gastric ulcer and the disorders that follow gastric surgery have received much attention, and du Plessis $e t$ al have emphasised that structural damage to the gastric mucosa may result. $^{5}$ If this is an important factor in Menetrier's disease, however, there should be greater changes in the antral mucosa.

Many of the clinical features are due to the large losses of water, electrolytes, and protein from the gastric mucosa. Most patients have serum concentrations of albumin under $35 \mathrm{~g} / \mathrm{l}$, while loss of immunoglobulin may impair the immune defences. Not surprisingly, the symptoms usually resist medical measures such as diet, antacids, and anticholinergics; and virtually all patients not treated by resection have chronic symptoms. But if specific antagonists to gastrointestinal hormones were developed they would be worth evaluating in view of these hormones' possible role in the disease. Irradiation to control the hyperplastic mucosa has given more unsatisfactory than good results. Understandably, surgeons are reluctant to advocate total gastrectomy, but partial resection yields a higher incidence of leaks from anastomoses than it does in peptic ulcer disease-possibly from suturing unhealthy gastric tissue. Total gastrectomy gives appreciably better results in this disorder than in gastric cancer, and, since it effectively eliminates the disease and abolishes the drain on protein and non-acid secretions, it seems to be the operation of choice-which removes the potential source of malignancy as an additional benefit.

Thus, just as in the Zollinger-Ellison syndrome, all we can offer sufferers, despite knowing so much about the mechanisms of the disease, is extirpation of the target organ. Nevertheless, we hope that we may soon be able to correct the deranged physiological machinery by some specific and effective pharmacological means.

1 Scharschmidt, B F, American fournal of Medicine, 1977, 63, 644.

2 Davis, J M, Gray, G F, and Thorbjarnarson, B, Annals of Surgery, 1977, $185,456$.

3 Berenson, M M, Sannella, J, and Freston, J W, Gastroenterology, 1976, 70, 257.

4 Johnson, L R, in Gastrointestinal Hormones, ed J C Thompson, p 215. Austin, University of Texas Press, 1975

5 Du Plessis, D J, in Topics in Gastroenterology-5, ed S C Truelove and E Lee, p 239. Oxford, Blackwell Scientific Publications, 1977. 